\title{
Ingestive behaviour, herbage intake and grazing efficiency of beef cattle steers on Tanzania guineagrass subjected to rotational stocking managements ${ }^{1}$
}

\section{Gelson dos Santos Difante ${ }^{2}$, Valéria Pacheco Batista Euclides ${ }^{3}$, Domicio do Nascimento Júnior ${ }^{4}$, Sila Carneiro da Silva ${ }^{5}$, Roberto Augusto de Almeida Torres Júnior ${ }^{6}$, Daniel Oliveira de Lucena Sarmento ${ }^{7}$}

\author{
${ }^{1}$ Pesquisa financiada pela Fundect e pelo CNPq. \\ 2 Programa de Pós-graduação em Zootecnia, UFV. Bolsista CNPq. \\ ${ }^{3}$ Embrapa Gado de Corte, Campo Grande, MS. \\ ${ }^{4}$ Departamento de Zootecnia, UFV. Bolsista CNPq. \\ 5 Departamento de Zootecnia, USP/ESALQ. \\ ${ }^{6}$ Embrapa Gado de Corte, Campo Grande, MS \\ 7 Doutorando do curso de Ciência Animal e Pastagens da USP/ESALQ.
}

ABSTRACT - The objective of this experiment was to evaluate the ingestive behaviour, herbage intake and grazing efficiency of beef cattle steers grazing on Panicum maximum Jacq. cv. Tanzania subjected to different rotational stocking intensities. Treatments corresponded to two post-grazing conditions (residues of 25 and $50 \mathrm{~cm}$ ) associated with a pregrazing condition of $95 \%$ sward canopy light interception during regrowth (LI). The grazing time increased linearly with the duration of the occupation period (475 to 630 minutes/day). On paddocks grazed down to a residue of $25 \mathrm{~cm}$, the bite rate increased linearly along the occupation period, with an average of 42.5 bites/minute. On paddocks grazed down to a residue of $50 \mathrm{~cm}$, the bite rate was stable and equal to $39 \mathrm{bites} /$ minute. There was no difference in herbage intake between grazing intensities. However, grazing at $25 \mathrm{~cm}$ residue resulted in greater herbage removal $(68.0 \mathrm{vs} .45 .6 \%)$ and greater grazing efficiency $(90.4$ vs. $49.8 \%)$ than grazing at $50 \mathrm{~cm}$ residue. Post-grazing residues of Tanzania guineagrass under rotational stocking management may be set at either 25 or $50 \mathrm{~cm}$, since the herbage intake was not affected within this grazing intensity range. However, herbage removal and grazing efficiency were reduced with the $50 \mathrm{~cm}$ post-grazing height and grazing time increased with long occupation periods.

Key Words: grazing management, $n$-alkanes, Panicum maximum, post-grazing height

\section{Comportamento ingestivo, consumo de forragem e eficiência de pastejo de novilhos em pastos de capim-tanzânia em pastejo rotativo}

RESUMO - O objetivo neste trabalho foi avaliar o comportamento ingestivo, o consumo e a eficiência de pastejo de novilhos em pastos de Panicum maximum Jacq. cv. Tanzânia submetidos a diversas intensidades de pastejo rotativo. Os tratamentos corresponderam a duas condições de pós-pastejo $(25$ e $50 \mathrm{~cm}$ ) associadas a uma condição de pré-pastejo (95\% de interceptação da luz incidente dossel forrageiro). O tempo de pastejo aumentou linearmente com o período de ocupação (475 a 630 minutos/dia). Em piquetes manejados com resíduo de $25 \mathrm{~cm}$, a taxa de bocados aumentou linearmente ao longo do período de ocupação, com média de 42,5 bocados/minuto. Em piquetes manejados com resíduo de $50 \mathrm{~cm}$, a taxa de bocados foi estável e igual a 39 bocados/minuto. Não houve diferença no consumo de forragem entre as intensidades de pastejo. No entanto, nos pastos manejados com $25 \mathrm{~cm}$ de resíduo, verificou-se maior remoção de forragem $(68,0$ vs $45,6 \%)$ e maior eficiência de pastejo $(90,4$ vs 49,8\%) que naqueles manejados com $50 \mathrm{~cm}$ de resíduo. Resíduos pós-pastejo em capim-tanzânia sob lotação rotativa podem ser fixados em 25 ou $50 \mathrm{~cm}$, pois o consumo de forragem não é afetado nessa amplitude de intensidade de pastejo. A remoção de forragem e a eficiência de pastejo são mais baixas nos pastos manejados com $50 \mathrm{~cm}$ de resíduo e o tempo de pastejo aumenta com longos períodos de ocupação dos piquetes.

Palavras-chave: altura pós-pastejo, manejo do pastejo, n-alcanos, Panicum maximum

\section{Introduction}

The daily amount of dry matter ingested is the most important measurement to allow for inferences regarding animal performance and responses (Burns et al., 1994). In spite of the enormous effort on the part of the scientific community, advances in obtaining reliable predictions of intake assessments in different feeding

Received January 14, 2008 and accepted February 6, 2009.

Corresponding author:gdifante@hotmail.com

*Correspondence address: Embrapa Gado de Corte, Rodovia BR 262 km 4, CP: 154, 79002-970, Campo Grande, MS 
systems have been limited (Kyriazakis, 2003; Carvalho et al., 2007).

The classic hypothesis found in literature is that herbage intake would be controlled by the capacity of the digestive tract to digest low-quality herbage and by the feedback mechanism of the nutrient metabolites absorbed when animals are fed with highly digestible diets. These are called physical and chemiostatic or physiological mechanisms, respectively (Conrad et al., 1964). However, Carvalho et al. (2001) argued that the sward structure would have a relatively greater importance than physical and chemiostatic mechanisms of satiety in a pastoral environment, and Da Silva \& Carvalho (2005) endorsed that by reporting the high animal performance indexes obtained in recent research on tropical pastures, where control of sward structure was an important feature of the experimental protocols used.

Cosgrove (1997) stated that it is difficult to predict herbage intake of animals on pastures under any circumstance. Much of this difficulty is due to the fact that herbage intake is influenced by several factors of the animal behaviour. Performance depends directly on daily herbage intake and indirectly on the effects of the grazing process on morphological composition, structural characteristics and herbage production (Palhano et al. 2005). Thus, knowledge about the mechanisms involved in the grazing process is important to understand aspects regarding control and regulation of herbage intake on pastures (Romney \& Gill, 2000).

Generally, intake and animal performance increase with increases in sward height, herbage mass, post-grazing residue and herbage allowance to a certain limit. This increase tends to a maximum specific value for each animal species and category that is characterized by their limitation to process and, or to digest the herbage ingested. Identifying this sward condition for each animal species and category allows comparison with the corresponding values for efficient herbage accumulation, resulting in the establishment of sward conditions that should be generated, so that pre-determined animal performance targets can be achieved (Da Silva \& Corsi, 2003).

Thus, the objective of this study was to assess herbage intake, ingestive behaviour, herbage removal and grazing efficiency of beef cattle steers on Panicum maximum Jacq. cv. Tanzania subjected to different rotational stocking intensities characterized by post-grazing heights of 25 and $50 \mathrm{~cm}$ and a common rest period corresponding to the time necessary for swards to reach $95 \%$ interception of the incident light during regrowth.

\section{Material and Methods}

The experiment was carried out at EMBRAPA - Gado de Corte, Campo Grande, MS, Brazil (20²7' S, 543' ' W and $530 \mathrm{~m}$ a.s.1.) on a Panicum maximum Jacq. cv. Tanzânia pasture established in January 1995 and used for grazing since August 1995. The use of the area for this experiment started in $09 / 29 / 2004$ and finished in $5 / 18 / 2005$, totalling 232 days. During the first 75 days (9/29 to 12/12/2004) the area was prepared for the experiment and activities involved such as collecting soil samples for chemical analysis, weed control, renovation and adjustments on fences and water lines and troughs, application of limestone and fertilizers, and mowing. The next 157 days (12/13/2004 to $5 / 18 / 2005$ ) corresponded to the experimental period itself, during which measurements were made and data were collected.

The climate in Campo Grande corresponds to the humid tropical type, sub-type Aw (Köppen classification), with a dry season during autumn and winter. Rainfall data were recorded on the experimental site and data for relative air humidity and temperatures recorded in a meteorological station located at approximately $800 \mathrm{~m}$ (Figure 1).

The soil in the experimental area is a Rhodic Ferralsol (FAO, 2006), and fertility was monitored aiming at maintaining levels from 50 to $70 \%$ base saturation, 8 to $12 \mathrm{mg} / \mathrm{dm}^{3}$ phosphorus (P-Mehlich) and 80 to $100 \mathrm{mg} / \mathrm{dm}^{3}$ potassium. Soil samples were collected on Sept. 30 and Oct. 01,2004 , being 12 from the $0-10 \mathrm{~cm}$ of depth, 12 from the $0-20 \mathrm{~cm}$ of depth and 12 from the $20-40 \mathrm{~cm}$ of depth, a total of 36 samples from each $2500 \mathrm{~m}^{2}$ paddock. The chemical analysis was performed according to EMBRAPA (1997) (Table 1).

Paddocks received $1000 \mathrm{~kg} / \mathrm{ha}$ of limestone, $800 \mathrm{~kg} / \mathrm{ha}$ of gypsum and $500 \mathrm{~kg} / \mathrm{ha}$ of a 0:20:20 compound fertiliser (N:P:K). Paddocks also received $150 \mathrm{~kg} /$ ha of $\mathrm{N}$ (urea), applied in instalments. Since the interval between successive grazing varied with treatments and time of the year, quantities and dates of $\mathrm{N}$ fertiliser application also varied, but ensuring that the same amount of fertiliser was used for each treatment at the end of the experimental period.

The experimental area was divided up into three 3.0 ha modules, with 12 paddocks each, totalling 9.0 ha. Each module was divided up into two sets of 6 paddocks $\left(2,500 \mathrm{~m}^{2}\right)$. One of the modules was used as a reserve area, where animals used for adjustments in the stocking rate were kept throughout the experiment. Two grazing intensity levels characterised by post-grazing heights of 25 and 


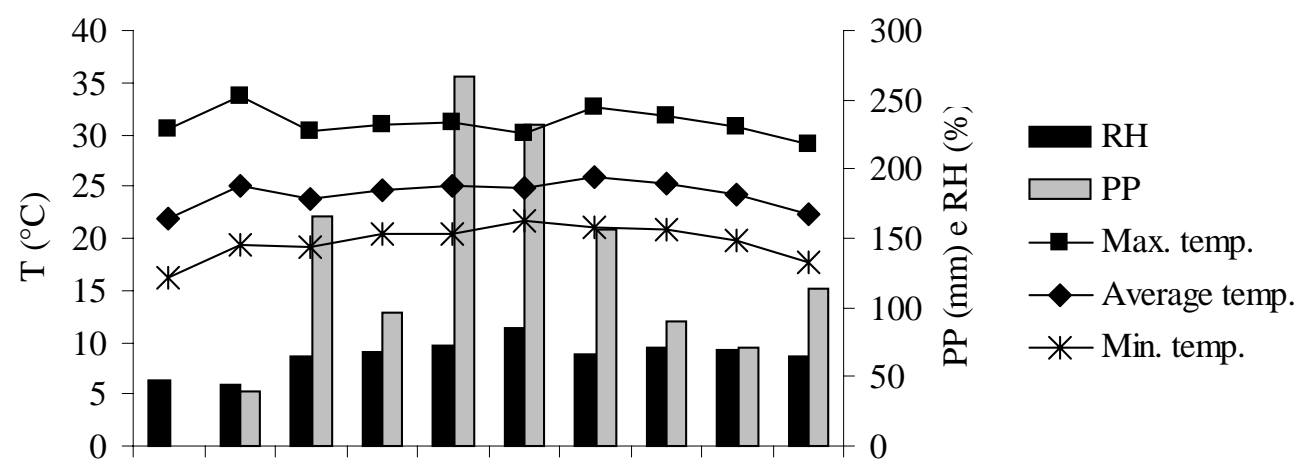

Aug Sep Oct Nov Dec Jan Feb Mar Apr May

Figure 1 - Rainfall (PP, mm), relative air humidity $(\mathrm{RH}, \%)$, maximum, average and minimum temperatures $\left({ }^{\circ} \mathrm{C}\right)$ during the experimental period.

Table 1 - Chemical characteristics of the soil on the experimental area at the $0-10 \mathrm{~cm}, 0-20 \mathrm{~cm}$ and $20-40 \mathrm{~cm}$ depths

\begin{tabular}{|c|c|c|c|c|c|c|c|c|c|c|}
\hline $\begin{array}{l}\text { Depth } \\
\mathrm{cm}\end{array}$ & $\begin{array}{c}P \\
\mathrm{mg} / \mathrm{dm}^{3}\end{array}$ & $\begin{array}{c}\mathrm{OM} \\
\%\end{array}$ & $\begin{array}{c}\mathrm{pH} \\
\mathrm{CaCl}_{2} \\
\end{array}$ & $\begin{array}{c}\mathrm{K} \\
\mathrm{mg} / \mathrm{dm}^{3}\end{array}$ & $\mathrm{Ca}$ & $\mathrm{Mg}$ & $\begin{array}{c}\mathrm{H}+\mathrm{Al} \\
\mathrm{cmol}_{\mathrm{c}} / \mathrm{dm}^{3}\end{array}$ & $S$ & $\mathrm{~T}$ & $\begin{array}{l}\mathrm{V} \\
\%\end{array}$ \\
\hline $0-10$ & 3.74 & 5.00 & 5.31 & 162.48 & 2.58 & 1.85 & 4.50 & 4.84 & 9.09 & 53.34 \\
\hline $0-20$ & 2.08 & 5.41 & 5.01 & 128.38 & 1.84 & 1.23 & 5.32 & 3.39 & 8.71 & 41.05 \\
\hline $20-40$ & 0.78 & 2.99 & 4.70 & 39.40 & 0.78 & 0.48 & 3.27 & 1.36 & 4.88 & 28.02 \\
\hline
\end{tabular}

$50 \mathrm{~cm}$ associated to a common pre-grazing condition characterised by $95 \% \mathrm{LI}$, and were designated as follows: $95 / 25=95 \% \mathrm{LI}$ pre-grazing and $25 \mathrm{~cm}$ post-grazing height $95 / 50=95 \% \mathrm{LI}$ pre-grazing and $50 \mathrm{~cm}$ post-grazing height

These were assigned to experimental units (sets of 6 paddocks) according to a complete randomised block design, with two replicates. The six paddocks per experimental unit allowed that each experimental unit was managed as a self-contained farmlet, with animals assigned to them corresponding to the "farmlet herd". A total of 24 paddocks were used for this purpose.

Grazing was carried out using 60 young Nellore bulls (approximately 12 months of age) with an average initial body weight of $221 \mathrm{~kg}$. The grazing method used was the rotational stocking, with variable stocking rate and rest period determined by the level of sward canopy light interception (LI). In November 2004, paddocks started to be grazed and mowed, soon after grazing, in order to ensure that the targets of post-grazing heights had been precisely achieved. Mowing was carried out on a weekly basis on one paddock per module with the objective of ensuring a regrowth gradient between paddocks within modules. This procedure was used until all paddocks of each module had been mowed.

Monitoring of canopy light interception was made throughout each regrowth cycle using a canopy analyser
AccuPAR Linear PAR/LAI ceptometer, Model PAR -80 (DECAGON Devices). At the beginning, the regrowth measurements were made on a weekly basis, starting at the post-grazing condition, but when readings started to get close to $90 \%$, the measurements were performed every two to three days until the target of $95 \%$ LI was reached. Readings were made along three transect lines with six sampling points each, totalling 18 sampling points per paddock. In each point, 1 reading was taken above the canopy and 5 at the ground level (optical sensor placed at the mid distance between tussocks), totalling 18 readings above the canopy and 90 at the ground level per paddock for each measurement date.

Sward height was measured using a $1 \mathrm{~m}$ ruler, and readings taken on 8 points randomly chosen along each of 5 transect lines across the paddocks, totalling 40 readings per paddock. At each point, the sward height corresponded to the distance between the ground and the horizon line defined by the curved top leaves around the ruler. Sward height measurements were made at the same dates that canopy light interception measurements were made throughout regrowth.

Pre-grazing herbage mass was determined by cutting two $1 \mathrm{~m}^{2}$ quadrats on three of the six paddocks of each experimental unit, totalling 6 quadrats per post-grazing conditions replication. Quadrats were placed on representative 
areas of the sward at the sampling time (visual assessment of herbage mass and height) using two $25 \mathrm{~cm}$ tall stands in order to achieve the cutting heights of 25 and $50 \mathrm{~cm}$. In each sampling point (quadrat), herbage was cut considering three strata: (1) above $50 \mathrm{~cm}$ from the ground; (2) between 50 and $25 \mathrm{~cm}$ from the ground; and (3) between $25 \mathrm{~cm}$ and ground level. From these samples, a sub-sample about halfsize the sample was separated, put into paper bags and dried in forced draught oven at $65^{\circ} \mathrm{C}$ until constant weight, which was used to calculate the dry matter content of the herbage and the dry weight of samples. Pre-grazing herbage mass was obtained as the sum of the herbage dry weight from the three strata. Another two sub-samples were generated and hand dissected into leaf (leaf blade), stem (stem + leaf sheath) and dead material. Components were dried in forced draught oven, similarly to the herbage mass samples, and dry weights were used to calculate the morphological composition of samples expressed as percentage. Post-grazing herbage mass and morphological composition were determined using procedure similar to that described for pre-grazing herbage mass.

The daily grazing time (minutes/day) was recorded on six animals (three per treatment) equipped with vibracorders with 24-hour recording capacity. Assessments were made throughout the occupation period of one paddock per treatment from 23/03/05 to 01/04/05, and recording cards replaced daily at 6 a.m. The bite rate (bites/minute) was determined from the time necessary for animals to perform 20 bites (Hodgson, 1982). For this, all test animals were observed during grazing activity periods, with several recordings performed on each animal. Means for each replication were generated from observations on each animal.

The herbage intake was estimated using controlled $n$-alkanes release capsules (Captec-New Zealand) (Mayes et al., 1986) on 13 animals, with an average body weight of $327 \mathrm{~kg}$. These were randomly distributed into groups of six and seven animals for the 50 and $25 \mathrm{~cm}$ post-grazing height, respectively. After a seven-day stabilization period of $n$-alkane release, daily faeces collections started, and were consistently performed at 6:00 a.m. and 6:00 p.m. during 10 days (23.03.05-01.04.05).

Samples of herbage as grazed were collected using two oesophageal fistulated animals everyday during the occupation period of a paddock. Fistulated animals were taken to a pen early in the morning, so cannules could be removed and collection bags attached to them. Animals were then taken to paddocks for a grazing period of approximately 20 minutes in each treatment. After sampling, animals were once again restrained to remove the collection bags and replace the cannules on the fistulae.

Faecal and extrusa samples were frozen shortly after collection. Processing of samples, after completion of the field work, involved drying in a forced draught oven at $55^{\circ} \mathrm{C}$ until constant mass and grinding. Processed samples were then used to generate one composite sample per animal per day. Both fecal and extrusa samples were subjcted to chemical analyses to determine their $n$-alkane profile. Herbage intake was estimated using the $\mathrm{C}_{33}$ : $\mathrm{C}_{32}$ pair and herbage digestibility using the $\mathrm{C}_{35}$, according to methodology reported by Oliveira (2004).

The stocking rate per grazing cycle was calculated as the product from the total mean body weight (testers and variable stock) by the number of days the animals remained in each module, according to Petersen \& Lucas Jr. (1968).

The herbage removal during grazing was calculated as the difference between pre-grazing green herbage mass (leaf + stem) and post-grazing green herbage mass. These values were transformed into percentage in relation to the pre-grazing green herbage mass. The grazing efficiency was calculated by dividing the total amount of herbage dry matter ingested (product of stocking rate during the paddock occupation period by the individual herbage intake) by the total amount of herbage removed during grazing (difference between pre and post-grazing herbage mass), and values were expressed as percentage.

The sward descriptive characteristics (light interception and pre and post-grazing heights) are presented using descriptive statistics only. Data were analysed using the PROC Mixed of SAS@ (SAS,1993), and means calculated using LSMEANS command. When appropriate, comparison of means was made using a $5 \%$ significance level by Tukey test.

\section{Results and Discussion}

Targets of pre-grazing sward light interception and post-grazing sward height were maintained relatively stable throughout the experimental period, regardless of post-grazing conditions (Table 2). Grazing to a postgrazing height of $25 \mathrm{~cm}$ was relatively more difficulty than to $50 \mathrm{~cm}$, a result of the animal reluctance to consume herbage at the end of the occupation period, with only $11.5 \%$ of leaves. There was no difference in pre-grazing herbage mass between post-grazing conditions, a likely consequence of the same target of sward light interception used to interrupt regrowth $(\mathrm{P}=0.0635)$. At post-grazing, herbage mass was lower for the 25 than the $50 \mathrm{~cm}$ post-grazing height $(\mathrm{P}=0.0006)$, a common and expected result for the higher grazing intensity associated with lower grazing residues. 
Table 2 - Sward height and pre and post-grazing herbage mass of tanzania guineagrass subjected to rotational stocking managements

\begin{tabular}{lcc}
\hline Item & \multicolumn{2}{c}{ Post-grazing conditions $(\mathrm{cm})$} \\
\cline { 2 - 3 } & 25 & 50 \\
\hline $\begin{array}{l}\text { Pre-grazing sward } \\
\text { height (cm) }\end{array}$ & 65.0 & 68.4 \\
$\begin{array}{l}\text { Post-grazing sward } \\
\text { height (cm) }\end{array}$ & 26.5 & 47.8 \\
$\begin{array}{l}\text { Pre-grazing herbage } \\
\text { mass (kg/ha of DM) }\end{array}$ & $7,130 \mathrm{a}(3.82)$ & $8,600 \mathrm{a}(3.21)$ \\
$\begin{array}{l}\text { Post-grazing herbage } \\
\text { mass (kg/ha of DM) }\end{array}$ & $3,810 \mathrm{~b}(372.30)$ & $5,080 \mathrm{a}(329.20)$ \\
\hline
\end{tabular}

Means followed by the same letter in lines are not different $(\mathrm{P}>0.05)$ - Tukey. Values in parentheses refer to the standard error.

The distribution of the pre-grazing herbage mass and its morphological components varied across the vertical profile of swards $(\mathrm{P}=0.0260$; Table 3$)$. There was a higher concentration of herbage mass at the bottom of the sward $(0-25 \mathrm{~cm})$, which decreased in the higher strata (25-50 and $>50 \mathrm{~cm}$ ). The morphological composition of the herbage mass also varied with sward vertical strata $(\mathrm{P}<0.010)$, with the lowest percentage of leaf at the bottom increasing towards the upper strata and the reverse occurring with stem and dead material. This herbage mass and morphological components distribution pattern is typical of pastures (Hodgson, 1990) and applies both to those formed by temperate and tropical plants (Stobbs, 1973, Palhano et al., 2007).

There was no difference between post-grazing conditions in daily herbage intake $(\mathrm{P}=0.3007)$, even though animals on the $50 \mathrm{~cm}$ post-grazing height consumed $7.1 \mathrm{~kg}$ $\mathrm{DM}$ and those on the $25 \mathrm{~cm}$ post-grazing height consumed $6.6 \mathrm{~kg} \mathrm{DM}(2.2 \times 2.0 \mathrm{~kg} / 100 \mathrm{~kg} \mathrm{LW})$ (Table 4). The digestibility of the consumed herbage was 68.5 and $67.3 \%$ for the 25 and $50 \mathrm{~cm}$ post-grazing height, respectively $(\mathrm{P}=0.6951)$.

In spite of no differences in daily herbage intake between post-grazing conditions, animals grazing at $50 \mathrm{~cm}$

Table 3 - Pre-grazing herbage mass (kg/ha of DM) and morphological composition (\%) of the vertical profile of tanzania guineagrass swards subjected to rotational stocking managements

\begin{tabular}{lcccc}
\hline Strata & Herbage mass & Leaf & Stem & Dead material \\
\hline$>50 \mathrm{~cm}$ & $990 \mathrm{c}(85.86)$ & $97.9 \mathrm{a}(1.62)$ & $1.1 \mathrm{c}(0.98)$ & $1.0 \mathrm{c}(1.87)$ \\
$25-50 \mathrm{~cm}$ & $2,420 \mathrm{~b}(85.86)$ & $75.8 \mathrm{~b}(1.62)$ & $12.3 \mathrm{~b}(0.98)$ & $11.9 \mathrm{~b}(1.87)$ \\
$0-25 \mathrm{~cm}$ & $4,350 \mathrm{a}(85.86)$ & $8.2 \mathrm{c}(1.62)$ & $30.5 \mathrm{a}(0.98)$ & $61.3 \mathrm{a}(1.87)$ \\
\hline
\end{tabular}

Means followed by the same lower case letter in columns are not differen (P>0.05) - Tukey.

Values in parentheses refer to the standard error.
Table 4 - Herbage intake, herbage removal and grazing efficiency in tanzania guineagrass subjected to rotational stocking managements

\begin{tabular}{lrrr}
\hline \multirow{2}{*}{ Item } & \multicolumn{2}{c}{$\begin{array}{c}\text { Post-grazing } \\
\text { conditions }\end{array}$} & \multirow{2}{*}{ Mean } \\
\cline { 2 - 3 } & \multicolumn{1}{c}{25} & \multicolumn{1}{c}{50} & \\
\hline Herbage intake $(\mathrm{kg} / 100 \mathrm{~kg} \mathrm{LW})$ & $2.0 \mathrm{a}$ & $2.2 \mathrm{a}$ & 2.1 \\
Herbage removal $(\%)$ & $68.0 \mathrm{a}$ & $45.6 \mathrm{~b}$ & 56.8 \\
Grazing efficiency $(\%)$ & $90.4 \mathrm{a}$ & $49.8 \mathrm{~b}$ & 70.1 \\
Digestibility of the & $68.5 \mathrm{a}$ & $67.3 \mathrm{a}$ & 67.9
\end{tabular}

consumed herbage $(\%)$

Means followed by the same lower case letter in lines are not different $(\mathrm{P}>0.05)$ - Tukey.

post-grazing height ingested $10 \%$ more dry matter than those grazing at $25 \mathrm{~cm}$. This was recorded during the short period of measurements used in this experiment (23 March to 01 April), but given the cumulative characteristic of this response, it could evolve to significant differences when considering the overall experimental period. The daily herbage intake was $2.1 \mathrm{~kg} / 100 \mathrm{~kg} \mathrm{LW}$, considered high for tropical pasture standards and compatible with daily gains of 664 and $801 \mathrm{~g} /$ animal.day (Difante, 2005). The digestibility of the consumed herbage was high (average of 68\%), and certainly a result of the higher percentage of leaf in the sward strata exploited by the grazing animals when grazing paddocks down to residue targets ( 75.8 and $97.9 \%$ for the 25-50 and $>50 \mathrm{~cm}$ strata, respectively; Table 3 ).

The herbage removal was also influenced by postgrazing conditions, with higher values registered when paddocks were grazed to 25 than to $50 \mathrm{~cm}$ (Table 4), indicating that higher post-grazing height resulted in lower grazing efficiency. However, the greater herbage removal on paddocks grazed to $25 \mathrm{~cm}$ resulted in lower sward residual leaf area and, consequently, lower canopy light interception soon after grazing, which caused the grazing interval to be longer (33 and 50 days for the 25 and $50 \mathrm{~cm}$ post-grazing height, respectively) and the number of grazing cycles to be smaller (Difante, 2005) under these circumstances.

Variation of herbage removal throughout the experimental period indicates little difference between grazing cycles as the experiment progressed (Figure 2), with values ranging from 37 to $53 \%$ and from and 62 to $73 \%$ for the 50 and $25 \mathrm{~cm}$ post-grazing heights. The grazing efficiency was higher and consequently grazing losses were lower for the 25 than for the $50 \mathrm{~cm}$ post-grazing height (90.4 and $49.8 \%$ and 9.6 and $49.8 \%$, respectively).

The grazing time increased linearly with the occupation period of paddocks (Figure 3), with recorded values ranging from 475 to 630 minutes/day ( 7.9 to 10.5 hours). This increase in grazing activity can be explained by the changes in sward 


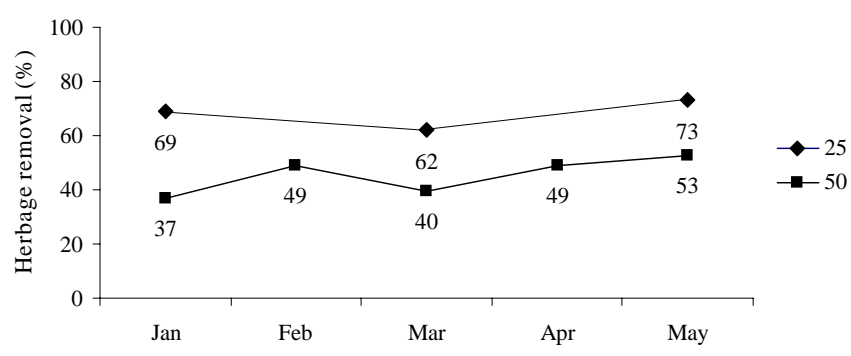

Figure 2 - Herbage removal (\%) in tanzania guineagrass swards subjected to rotational stocking managements.

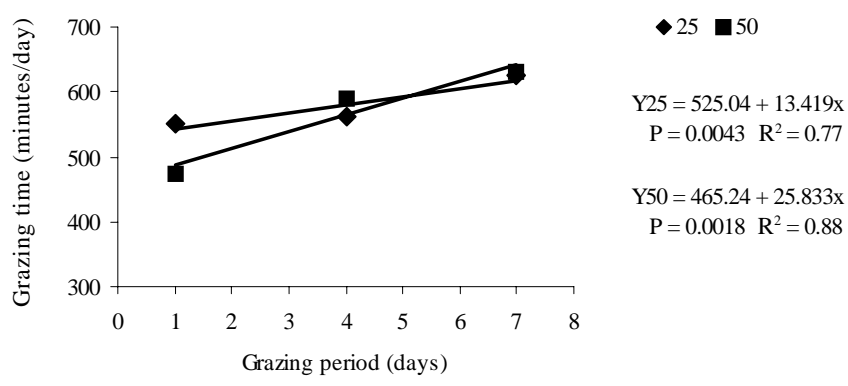

Figure 3 - Grazing time (minutes/day) of beef cattle steers during the grazing down period of Tanzania guineagrass subjected to rotational stocking managements.

structural characteristics during the three days that animals remained on paddocks, particularly sward height and morphological composition of the herbage mass (Table 3). The grazing time increased 13.4 and 25.8 minutes for each occupation day when swards were grazed to 25 and $50 \mathrm{~cm}$, respectively. These results are in line with those of Trindade et al. (2007), who described variation in sward structure during the grazing process of marandu pallisadegrass. The authors explained variations in the grazing behaviour such as increase in grazing time, reduction in bite size etc. as being related to the reduced probability of encountering leaves as herbage during the occupation period of paddocks. Carvalho et al. (2001) also reported similar response pattern at the beginning and end of the occupation period of paddocks. At the beginning, the amount of herbage available is very high and leaves are the main component in the upper strata of swards. As grazing progress and herbage is removed from paddocks, the herbage available is reduced and the presence of leaves diminished in the medium/lower remaining strata, leading animals to change the grazing behavior spending more time searching for leaves and when encountering them, taking smaller bites because of physical limitations imposed by herbage characteristics.

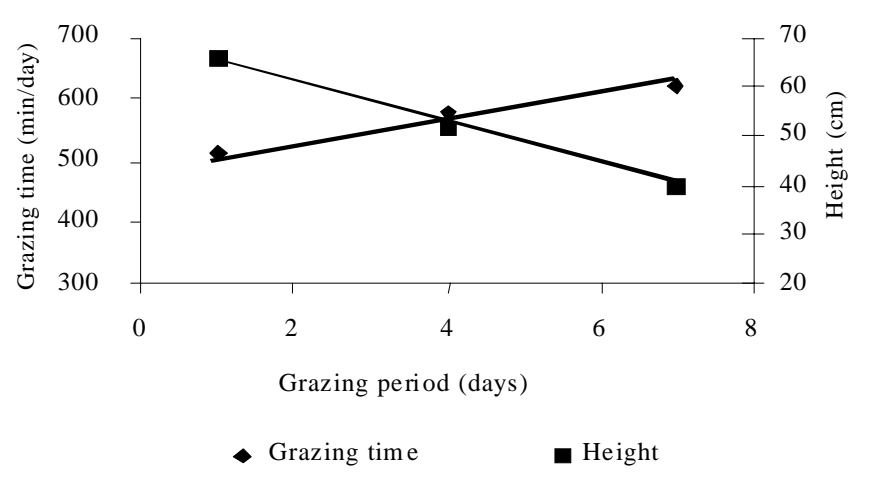

Figure 4 - Relationship between grazing time (minutes/day) and sward height during the grazing process of tanzania guineagrass swards subjected to rotational stocking managements.

The grazing time had a negative correlation $(\mathrm{r}=-0.59)$ with sward height $(\mathrm{P}=0.0191$; Figure 4$)$. This finding was also reported by Hendricksen \& Minson (1980), in an experiment where the grazing time increased as the percentage of leaf in sward herbage mass decreased.

The average bite rate on swards grazed to $25 \mathrm{~cm}$ was 42.5 bites/minute and varied linearly with occupation days at a rate of 0.64 bite/minute (Figure 5). This represents 371 additional bites for each additional occupation day. On swards grazed to $50 \mathrm{~cm}$, the bite rate did not vary during the occupation period and averaged 39.1 bites/minute, indicating that the higher post-grazing residue did not interfere severely enough with the sward structure in order to cause variations in bite harvesting.

The inverse relationship between bite rate and sward height during the occupation period of paddocks $(r=-0.91$; $\mathrm{P}<0.0001$ ) (Figure 6). This variation pattern is in agreement with results of Sarmento (2003), who reported reduction in

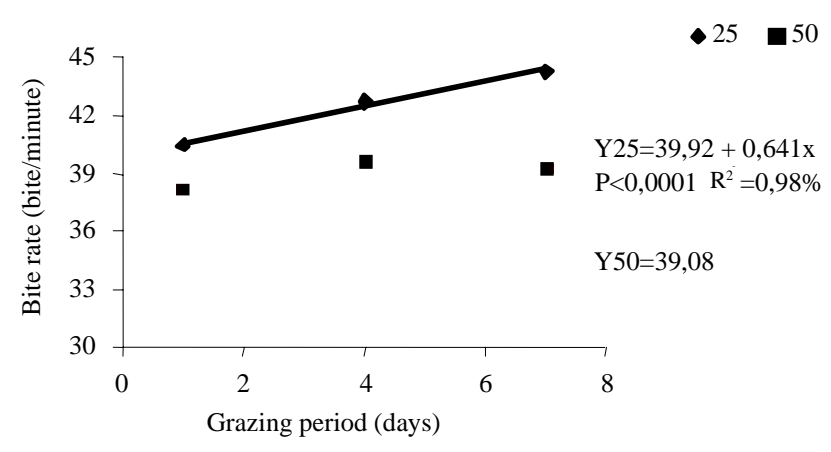

Figure 5 - Bite rate (bites/minute) of beef cattle steers during the grazing period of Tanzânia guineagrass swards subjected to rotational stocking managements. 


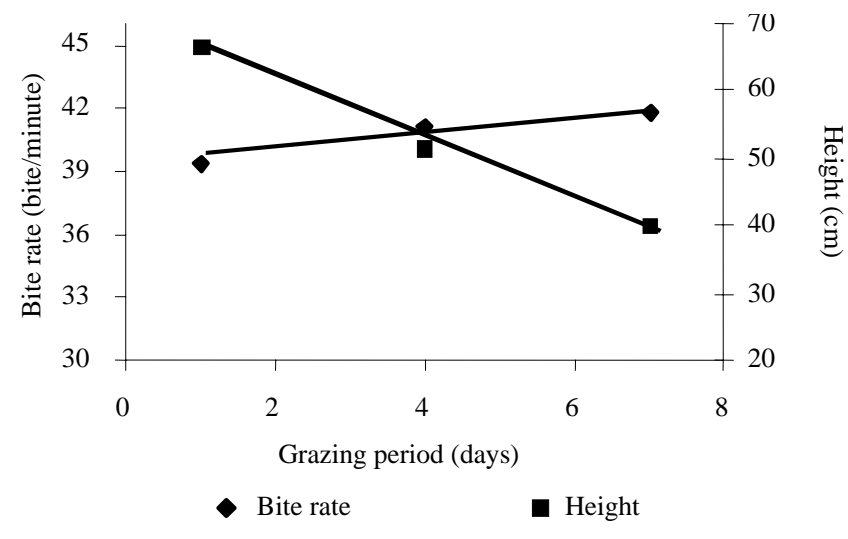

Figure 6 - Relationship between bite rate (bites/minute) and sward height during the grazing process of tanzania guineagrass swards subjcted to different rotational stocking intensities.

bite weight with decreasing heights of potentially grazed strata and herbage mass on swards. Under these circumstances, animals responded to increasing bite rate and grazing time.

\section{Conclusions}

Tanzania guineagrass subjcted to different rotational stocking intensities can be managed at either 25 or $50 \mathrm{~cm}$ post-grazing height without interfering with daily herbage intake of the grazing animals, but herbage removal and grazing efficiency are higher with the lower residue. Long occupation periods can result in considerable increase in grazing activity of the animals.

\section{Acknowledgements}

The authors would like to thank the Universidade Federal de Viçosa for the opportunity; EMBRAPA - Gado de Corte, for the infra-structure and technical support; Fundação de Apoio ao Desenvolvimento do Ensino, Ciência e Tecnologia do Estado de Mato Grosso do Sul - Fundect, for partial funding to the project; Conselho Nacional de Desenvolvimento Científico e Tecnológico-CNPq, for the sponsorship to the first author; and Dr. Dimas Estrásulas de Oliveira, for assistance with the $n$-alkane analyses.

\section{Literature Cited}

BURNS, J.C.; POND, K.R.; FISHER, D.S. Measurement of forage intake. In: FAHEY JR., G.C. (Ed.) Forage quality, evaluation, and utilization. Lincoln: American Society of Agronomy, 1994. p.494-532.
CARVALHO, P.C.F.; KOZLOSKI, G.V.; RIBEIRO FILHO, H.M.N. et al. Avanços metodológicos na determinação do consumo de ruminantes em pastejo. Revista Brasileira de Zootecnia, v.36, suplemento especial, p.151-170, 2007.

CARVALHO, P.C.F.; RIBEIRO FILHO, H.M.N.; POLI, C.H.E.C. et al. Importância da estrutura da pastagem na ingestão e seleção de dietas pelo animal em pastejo. In:REUNIÃO ANUAL DA SOCIEDADE BRASILEIRA DE ZOOTECNIA, 38., 2001, Piracicaba. Anais... Piracicaba: Fundação de Estudos Agrários Luiz de Queiroz, 2001. p.853-871.

CONRAD, H.R.; PRATT, A.D.; HIBBS, J.W. Regulation of feed intake in dairy cows. I. Change in importance of physical and physiological factors with increasing digestibility. Journal of Dairy Science, v.47, p.54-62, 1964.

COSGROVE, G.P. Grazing behavior and forage intake. In: INTERNATIONAL SYMPOSIUM ON ANIMAL PRODUCTION UNDER GRAZING, 1., 1997, Viçosa, MG. Anais... Viçosa, MG: Universidade Federal de Viçosa, 1997. p.59-80.

DA SILVA, S.C.; CORSI, M. Manejo do pastejo. In: SIMPÓSIO SOBRE O MANEJO DA PASTAGEM, 20., 2003, Piracicaba. Anais... Piracicaba: Fundação de Estudos Agrários Luiz de Queiroz, 2003. p.155-186.

DA SILVA, S.C.; CARVALHO, P.C.F. Foraging behaviour and intake in the favourable tropics/sub-tropics. In: McGILLOWAY, D.A. (Ed.) Grassland: a global resource. Netherlands: Wageningen Academic Publishers, 2005. p.81-95.

DIFANTE, G.S. Desempenho de novilhos, comportamento ingestivo e consumo voluntário em pastagem de "Panicum maximum" Jacq. cv. Tanzânia. Viçosa, MG: Universidade Federal de Viçosa, 2005. 74f. Tese (Doutorado em Zootecnia) Universidade Federal de Viçosa.

EMPRESA BRASILEIRA DE PESQUISA E AGROPECUÁRIA EMBRAPA - Centro Nacional de Pesquisa de Solos. Manual de métodos de análise química do solo. 2.ed. Brasília: 1997. $212 \mathrm{p}$.

HENDRICKSEN, R.; MINSON, D.J. The intake and grazing behaviour of cattle grazing a crop of Lablab purpureus cv. Rongai. Journal of Agricultural Science, v.95, p.547-554, 1980 .

HODGSON, J. Ingestive behavior. In: LEAVER, J.D. (Ed.) . Herbage intake handbook. Wallingford: British Grassland Society, 1982. p.113-138.

HODGSON, J. Grazing management: science into pratice. New York: J. Wiley, Longman Scientific and Technical, 1990. 203p.

FAO [2006]. IUSS Working Group WRB. World reference base for soil resources 2006. Rome: FAO (World Soil Resources Reports, 103). Disponível em: <http://www.fao.org/ag/Agl/agll/wrb/doc/ wrb2006final.pdf>. Acesso em: 20/8/2007.

KYRIAZAKIS, I. What are ruminant herbivores trying to achieve through their feeding behavior and food intake? In: INTERNATIONAL SYMPOSIUM ON THE NUTRITION OF HERBIVORES, 6., 2003, Yucatan. Proceedings... Yucatan: 2003. p. 154-173.

MAYES, R.W.; LAMB, C.S.; COLGROVE, P.M. The use of dosed and herbage n-alkanes as markers for determination of herbage intake. Journal of Agricultural Science, v.107, n.1, p.161-170, 1986.

OLIVEIRA, D.E. Determinação de alcanos - Manual de extração e análise cromatográfica em forragens, concentrados e fezes. Piracicaba: Fundação de Estudos Agrários Luiz de Queiroz, 2004. 30p.

PALHANO, A.L.; CARVAlHO, P.C.F.; DITTRICH, J.R. et al. Estrutura da pastagem e padrões de desfolhação em capimmombaça em diferentes alturas do dossel forrageiro. Revista Brasileira de Zootecnia, v.34, n.6, p.1860-1870, 2005.

PALHANO, A.L.; CARVALHO, P.C.F.; DitTRICH, J.R. et al. Características do processo de ingestão de forragem por novilhas holandesas em pastagens de capim-mombaça. Revista Brasileira de Zootecnia, v.36, n.4, p.1014-1021, 2007 (supl. 1). 
PETERSEN, R.G.; LUCAS JR., H.L. Computing methods for the evaluation of pastures by means of animal response. Agronomy Journal, v.60, p.682-687, 1968.

ROMNEY, D.L.; GILL, M. Intake of forages. In: GIVENS, D.I.; OWEN E.; AXFORD, R.F.E. et al. (Eds.) Forage evaluation in ruminant nutrition. Wallingford: CAB International, 2000, p.43-62.

SARMENTO, D.O.L. Comportamento ingestivo de bovinos em pastos de capim-Marandu submetidos a regimes de lotação contínua. 2003. 76f. Dissertação (Mestrado em Agronomia Ciência Animal e Pastagens) - Escola Superior de Agricultura Luiz de Queiroz, Piracicaba, 2003.
STATISTICAL ANALYSIS SYSTEM - SAS. SAS/STAT: user's guide statistics, versão 6, 4.ed. Cary: 1993 v.1,2.

STOBBS, T.H. The effects of plant structure on the intake of tropical pastures. I. Variation in the bite size of grazing cattle. Australian Journal of Agricultural Research, v.24, p.809-819, 1973.

TRINDADE, J.K.; DA SILVA, S.C.; SOUZA JR., S.J. et al. Composição morfológica da forragem consumida por bovinos de corte durante o rebaixamento do capim-marandu submetido a estratégias de pastejo rotativo. Pesquisa Agropecuária Brasileira, v.42, n.6, p.883-890, 2007. 